\title{
Beyond Yield: Plant Disease in the Context of Ecosystem Services
}

\author{
M. R. Cheatham, M. N. Rouse, P. D. Esker, S. Ignacio, W. Pradel, R. Raymundo, \\ A. H. Sparks, G. A. Forbes, T. R. Gordon, and K. A. Garrett
}

First author: Department of Agricultural and Biosystems Engineering, Iowa State University, Ames 50011; second, third, seventh, and tenth authors: Department of Plant Pathology, Kansas State University, Manhattan 66506; fourth author: CATIE, Turrialba, Costa Rica; fifth, sixth, and eighth authors: Centro Internacional de la Papa (CIP), Lima, Peru; and ninth and tenth authors: Department of Plant Pathology, University of California-Davis, 95616.

Current address of M. R. Cheatham: Department of Environmental Science and Tech., University of Maryland, College Park 20742; and Beltsville Agricultural Research Center, United States Department of Agriculture, Beltsville, MD, 20705.

Current address of P. D. Esker: Department of Plant Pathology, University of Wisconsin, Madison, 53706.

Current address of M. N. Rouse: Department of Plant Pathology, University of Minnesota, St. Paul, 55108.

Accepted for publication 13 May 2009.

\begin{abstract}
Cheatham, M. R., Rouse, M. N., Esker, P. D., Ignacio, S., Pradel, W., Raymundo, R., Sparks, A. H., Forbes, G. A., Gordon, T. R., and Garrett, K. A. 2009. Beyond yield: Plant disease in the context of ecosystem services. Phytopathology 99:1228-1236.

The ecosystem services concept provides a means to define successful disease management more broadly, beyond short-term crop yield evaluations. Plant disease can affect ecosystem services directly, such as through removal of plants providing services, or indirectly through the effects of disease management activities, including pesticide applications, tillage, and other methods of plant removal. Increased plant biodiversity

play similar roles. Distant ecosystems may provide a disservice as the setting for the evolution of pathogens that later invade a focal ecosystem, where plants have not evolved defenses. Conversely, distant ecosystems may provide a service as sources of genetic resources of great value to agriculture, including disease resistance genes. Good policies are needed to support conservation and optimal use of genetic resources, protect ecosystems from exotic pathogens, and limit the homogeneity of agricultural systems. Research is needed to provide policy makers, farmers, and consumers with the information required for evaluating trade-offs in the pursuit of the full range of ecosystem services desired from managed and native ecosystems.
\end{abstract} may reduce disease risk if susceptible host tissue becomes less common, or may increase risk if additional plant species are important in completing pathogen life cycles. Arthropod and microbial biodiversity may
Additional keywords: biological control.
Ecosystem services are processes by which the environment supplies benefits to humans (23). Evaluations of interactions between humans and the environment, such as the Millennium Ecosystem Assessment (MEA) (64), commonly use the ecosystem services framework. In the MEA, ecosystem services are divided into four broad categories. Provisioning services include production of food, water, fiber, fuel, and genetic resources. Supporting services include primary biomass production, nutrient cycling, nitrogen fixation, and soil formation. Regulating services include regulation of climate, water quality, disease and arthropod pests, natural hazards, and pollination. Cultural services include inspiration for art and spirituality, as well as opportunities for recreation, ecotourism, and education. Ecosystems may also supply "disservices", such as air pollution from natural fires in the short run or, in the long run, they may provide the biological settings for the evolution of pathogens that later invade other regions.

In agricultural systems, the production of food, fiber, and biofuels are the ecosystem services most typically valued and evaluated. Other services may be of equal or greater value, especially cumulatively, including effects on water and air quality; habitat and food sources for beneficial insects, wildlife, and other organisms valued by society; carbon sequestration; pollination; and disease suppression (92). These benefits often receive less

Corresponding author: K. A. Garrett; E-mail address: kgarrett@ksu.edu

doi:10.1094/PHYTO-99-11-1228

(c) 2009 The American Phytopathological Society attention because they are more difficult to quantify. Agricultural activities can also move excess nutrients, pesticides, and other pollutants into surrounding landscapes via wind or water. Balance is needed between production of food to satisfy global needs and maintenance of the other services supplied by agroecosystems and other ecosystems. And, although this article emphasizes benefits to humans, it is also important to keep in mind the ethical responsibilities humans have to other species, whether or not those species provide clear benefits to humans.

Our objectives in this synthesis are to (i) develop a framework for inclusion of plant disease in assessments of ecosystem services and for evaluations of successful plant disease management that go beyond crop yield; (ii) synthesize the interactions of policy, biodiversity, global resources, and management decisions as they impact ecosystem services; and (iii) point out research needs for improved evaluation of plant disease in the context of ecosystem services. Our conceptual framework for this system is illustrated in Figure 1. The listing of potential ecosystem services along the right side of Figure 1 generally follows the presentation in the MEA (64). We review and discuss how the other components of this system influence ecosystem services, particularly via effects on plant disease and the methods used to manage plant disease. The headings of the sections of the text also correspond to Figure 1.

Effects of plant disease pressure on ecosystem services (A to D). The most commonly considered impact of plant disease is on provisioning services, generally in terms of crop yield, though broad estimates of yield loss due to plant disease are rare. Oerke et al. (76) estimated that $42 \%$ of the preharvest yield of the eight 


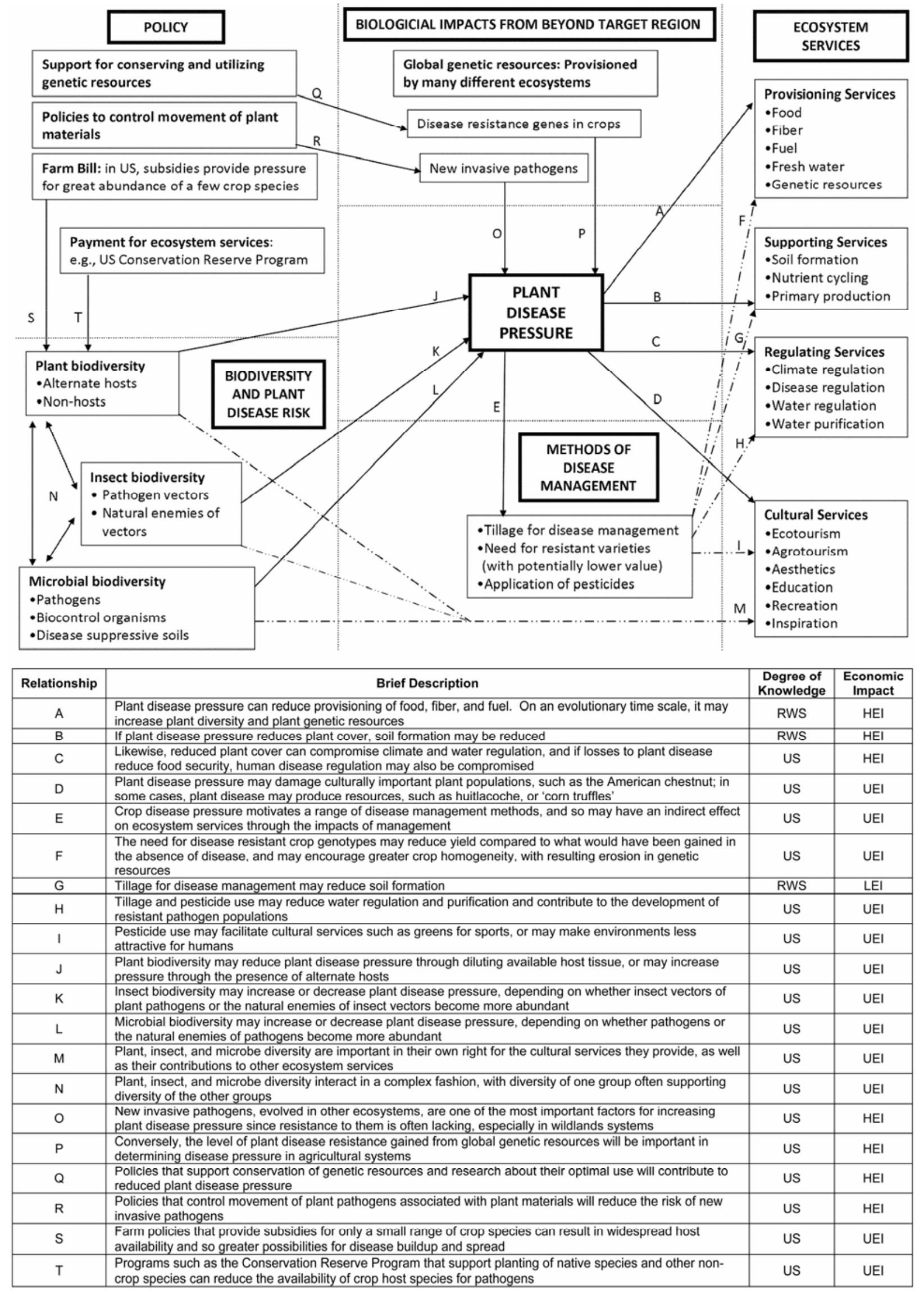

Fig. 1. Conceptual diagram representing the links between ecosystem services, plant disease and disease management, biodiversity, global genetic resources, and policy. Specific relationships are discussed briefly in the accompanying table and in more detail in the text. Each relationship is evaluated in terms of the degree of knowledge we have about it (RWS = relatively well-studied and US = understudied) and the likely economic impact (HEI = higher economic impact, LEI = lower economic impact, or UEI = unknown economic impact). 
most important crop species is lost to combined disease and pest damage. Total global food production losses to plant disease have been estimated at $10 \%(95,102)$. Plant disease can also impact provisioning services outside cropping systems. When chestnut blight (caused by Cryphonectria parasitica (Murrill) M. E. Barr) reduced American chestnut trees (Castanea dentata (Marsh.) Borkh.), once the dominant tree in many forests on the east coast of the United States, to understory sprouts and bushes, the provisioning services provided by this tree, such as rot-resistant timber, tannin for tanning leather, and chestnuts for food, were significantly reduced in availability (12). Negative effects of disease on ecosystem services can also result simply from alterations in community structure. Thus, for example, logging operations provided novel infection courts (tree stumps) for a resident woodrotting fungus (Heterobasidion annosum), which became a significant cause of tree mortality by colonizing stumps and moving through root grafts to infect adjacent healthy trees (91). The loss of merchantable timber constituted a fairly immediate impact on provisioning services, and longer-term impacts on supporting and regulatory services may result as well.

On an evolutionary time scale, plant disease may have contributed to current provisioning services, including genetic resources, as a driver of diversification in plant communities (41). On shorter time scales, plant disease may reduce genetic resources through reductions in numbers and diversity of particular plant species. For example, Phytophthora cinnamomi, introduced to Australia, has had devastating effects on native vegetation, and even effects on fauna, such that it has been listed as a process that threatens Australia's biodiversity (14). Although plant disease generally provides disservices within agricultural systems, it may also provide provisioning services. For example, the corn smut fungus produces huitlacoche, or "corn truffles", an edible delicacy. And infection of grapes by Botrytis cinerea can produce "noble rot" wines (89).

Plant disease effects on supporting services have received much less research attention. The effects of plant disease on processes such as soil formation, nutrient cycling, and primary productivity will be most important when (i) disease removes plant tissue so quickly that compensatory growth by the same or other plant species cannot replace the function of the damaged plants or (ii) the functional diversity of a plant community is low, so that the role that was played by the diseased plants is not effectively replaced by other plant types. Eviner and Likens (30) developed a conceptual framework for the impact of plant disease on biogeochemical cycling.

Scenarios in which plant disease may affect regulating services, such as climate regulation, water regulation, and water purification, will generally be similar to those in which supporting services are affected: cases where plant function is disrupted by disease and other plant types cannot compensate. Plants act as a sink for the carbon stored in their tissues, which is stored in the form of plant tissues, and also help reduce soil loss because the plant canopy slows the velocity of rain and the roots secure soil. In California, many stands of oak and other tree species (Lithocarpus densiflorus and Quercus spp.) are being damaged by sudden oak death (caused by $P$. ramorum) (90) while Monterey pine (Pinus radiata D. Don) stands are damaged by pitch canker (caused by Fusarium spp.) (42). When these trees die, the dry plant material can easily catch fire, releasing carbon into the atmosphere and increasing the potential for soil loss, particularly during flood events. Regulation of disease, itself, is another potential ecosystem service. Regulation of plant disease through ecosystem biodiversity is addressed in more detail below. Nutrient availability may influence plant disease resistance, availability of water may have important effects on the likelihood of infection by many pathogens (49), and temperature effects on pathogen infection processes and overwintering may determine disease severity (36). Finally, plant disease may help to regulate the abundance of invasive plant species, with or without intentional deployment of disease by humans.

Plant disease may have important impacts on cultural services through the removal of well-loved plant species by invasive specialist pathogens, or through the disruption of whole plant communities by invasive generalist pathogens such as Phytophthora cinnamomi. Elm trees (Ulmus spp.) are a favorite in U.S. landscaping for their vase-shaped architecture but, in many areas where trees became infected by Dutch elm disease (caused by Ophiostoma spp.), elm trees could no longer be grown (96). In another instance, forests in the northeastern United States that once were made up of large, mature American beech trees (Fagus grandifolia Ehrh.) were converted to thick stands of smaller beech trees after the effects of beech bark disease (Nectria spp.) (48). White pine blister rust (75) provides another example of diminished services from native ecosystems resulting from the introduction of an invasive pathogen.

Effects of disease management on ecosystem services ( $E$ to I). Plant diseases can indirectly impact ecosystem services through the effects of disease management practices, such as tillage and the use of pesticides. For example, tillage is used to bury or remove plant residues that may harbor pathogens and herbicides are used to kill plants that might act as hosts to maintain pathogen and vector populations. When tillage practices leave little residue in agricultural fields, there is greater potential for soil erosion by wind and water, resulting in reduced top soil and removal of nutrients, air pollution from wind-blown soil, and loss of soil structure leading to reduced infiltration of water and increased runoff $(2,65,114)$. Likewise, tillage and herbicide application leave little or no cover for wildlife that rely on the vegetation in fields, fence rows, and other habitats bordering fields for shelter and sources of food (5).

Although the vast majority of plant species that grow as weeds or grow in areas surrounding agricultural fields provide a diseaseregulating effect by diluting availability of susceptible crop hosts, some weed species may provide a disservice by benefiting crop pathogens. For example, weeds might serve as alternate hosts necessary to complete a pathogen's life cycle (1) or as reservoirs for a pathogen or its vector. This can create pressure for summer tillage and herbicide use (11), which may enhance disease management but may also diminish other ecosystem services. For example, the elimination of monocotyledonous hosts to Wheat streak mosaic virus (WSMV) found near economically important host crops such as wheat, maize, and sorghum $(19,99)$ has been implicated in reduced populations of another economically important species, the pheasant, in Kansas (93). In the case of WSMV it may be possible to adjust the timing and type of management so that the "green bridge" is broken far enough in advance of fall planting (51) but maintained long enough to support wildlife through the summer. Rust fungi offer another example of pathogen use of multiple host species. The wheat stem rust pathogen Puccinia graminis f. sp tritici has a polycyclic life cycle, using barberry species (Berberis spp.) as alternate hosts for sexual reproduction (82). Many barberry species are native to North America, as well as being popular in horticultural plantings and providing food for birds, but barberry eradication programs were implemented for wheat disease management.

The use of pesticides for disease management is well recognized for its potential to impact ecosystem services. This has motivated the development of trade-off analyses to evaluate both the economic return and environmental impact of management activities. Trade-off analysis may use a simple linear model for comparisons between two variables, one economic (return or profit) and one environmental (e.g., methane emission) (88), or a more complex approach, such as the one developed by Groot et al. (43) with the goal of maximizing agricultural profit as well as conservation of natural resources and landscape quality. One approach is to use an index for standardizing the impact of pesti- 
cides. For example, Kovach et al. (56) developed the Environmental Impact Quotient (EIQ) to compare the risk of pesticides to environmental and human health. The EIQ is divided into measures for three constituencies that experience risk from pesticides: farm workers, consumers, and wildlife. Other methods, such as the Environmental Hazard Index (EHI) (78) and the Priority Substances List (PSL) score (55), were developed within the same decade but didn't have the success of the EIQ because of the difficulty in obtaining the measurements needed (34). Gallivan et al. (34) also found a lack of agreement among these scoring systems.

Fungicides can affect all types of environmental services: supporting, provisioning, regulating, and cultural. Frequent use of fungicides and direct applications to soil likely affect one or more aspects of nutrient cycling, but the role of fungicides appears to be very complex. For example, the fungicides benomyl, captan, and chlorothalonil were all found to alter one or more parameters of nutrient cycling but the effects were fungicide specific and shifted when soils were amended with organic matter (18). It also appears that the effects of particular compounds may be synergistic (26). There is little doubt that fungicides can affect soil microbiota, particularly fungi, including mycorrhizae (100); however, overall nutrient cycling in soil can be very robust to addition of some fungicides (40). Some natural ecosystems are very sensitive to nontarget contamination by fungicides. Fungicides containing copper have been widely studied for their environmental effects. These fungicides are applied frequently and in large amounts on perennial crops such as avocados and grapes $(85,109)$ leading to a buildup of copper in soils that can reduce biological activity and fertility (28). Mercury buildup from nowbanned mercury-based fungicides threaten coral reefs (62). Current tin-based fungicides are a source of toxic tin compounds found in waterways and fish $(52,60)$. Certain fungicides may also have unwanted secondary effects on natural predators, such as entomopathogenic fungi (58) or nematodes (57). Fungicide contamination of groundwater resources is a major problem in many parts of the world. The U.S. Environmental Protection Agency developed a nationwide strategy in the early 1990s to help states develop pesticide management plans to reduce the risk of groundwater contamination (4). In developing countries, fungicide contamination (and pesticide contamination in general) may occur in ways previously unsuspected. By using fluorescent dyes, researchers in Ecuador identified contamination pathways around farm homesteads that led to exposure of all family members, not just the person responsible for application (115).

Fungicides may support provisioning services of the environment in several ways. The most obvious of these is by increasing the productivity of agricultural systems through disease suppression. High agricultural productivity levels may have spared some marginal lands that otherwise would have been required to maintain production levels in the past (92). However, there is a need to view agricultural productivity in the context of positive and negative side effects (externalities), many of which are related to environmental contamination with pesticides, as estimates of productivity change when these externalities are included $(6,104)$. Models involving externalities can provide powerful tools for plant pathologists to generate more realistic estimates of the impact of disease management strategies that reduce pesticide usage or involve less dangerous pesticides.

Another important issue pathologists may investigate is misuse of fungicides in conventional disease management practices. Improving farmer knowledge in developing countries has, at times, led to improved productivity with no increase or even a reduction in pesticide use (105). Similarly, workers at the International Potato Center (unpublished) using an EIQ found that the highest EIQ levels were not necessarily associated with increased productivity, because pesticides may be used unnecessarily or farmers may use products associated with a high health risk. Use of highly toxic substances may simply reflect lack of farmer knowledge of less-toxic alternatives (77). The prospect of gaining ecosystem services through training farmers for improved disease management in developing countries could lead to creative mechanisms of financing this type of development.

Fungicides are also used to support cultural services provided by the environment. For example, in Britain, golf courses typically receive four times as many pesticides as cereals, most of which are fungicides (39).

Biodiversity and plant disease risk ( $J$ to $P$ ). The general effects of biodiversity on productivity and ecosystem services as a whole are the subject of many reviews $(44,68)$. Ecologists have focused a great deal of attention on the effects of biodiversity on such ecosystem traits as biomass production and invasibility. Biodiversity may contribute to productivity through several mechanisms. Most simply, the more plant species there are, the more likely it is that the ecological community will include one or more highly productive taxa. On an evolutionary time scale, plant pathogens may contribute to biodiversity through selection pressures for plant genotypes resistant to disease (41). Plant pathogens may also help to maintain more diverse plant communities if disease severity is dependent on host frequency or density.

Modern agriculture obviously imposes rather severe limitations on diversity by favoring monocultures or two-crop rotations (35), and current conventional strategies for high levels of food production militate against a reversal of this tendency. However, a better understanding of how landscape structure and heterogeneity influences interactions between host, pathogen, and environment may suggest realistic alterations that can reduce the impacts of plant diseases. One obvious approach would be to increase heterogeneity of the landscape, thus diminishing intense selection pressure for virulent pathogen populations. Increasing the number of plant species and within-species genotypic diversity (87) can lead to (i) a lower rate of encounter between a susceptible host and infectious individuals, such as vectors; (ii) a reduced probability that transmission occurs given an encounter has happened; (iii) reduced host density (lower host availability); and (iv) increased death rate (limiting the development of widescale epidemics by only affecting a smaller patch) $(15,53)$. On the other hand, in some cases, a more heterogeneous landscape might favor pathogen and vector movement between patches of hosts $(7,9,13,81,113)$.

Native ecosystems may also be subject to reductions in biodiversity and changes in community structure through humanmediated activities such as urbanization and commercial development. For example, fragmentation resulting from patchwork development on forest margins may render remaining stands more prone to invasion by exotic pathogens (112). As another example, Castello et al. (16) noted that white ash decline and ash yellows were more severe where the forest was composed of many fragmented stands, apparently because the insect vector could more easily access hosts at the edges of fragments. Even where heterogeneity effectively separates susceptible populations, human activities may negate this effect by, for example, movement of Phytophthora ramorum in soil on hiker's shoes (24).

Heterogeneity has both spatial and temporal components and both are amenable to manipulation. Spatial diversity can be enhanced through the use of mixtures of two or more genotypes of the same crop $(37,69)$. One striking example of the potential positive effects of this approach is in the use of a rice cultivar mixture to manage rice blast in China. In this case, a mixture of a susceptible, high-value cultivar and a resistant, low-value cultivar produced a susceptible cultivar yield that was $89 \%$ greater than in monoculture, and rice blast was $94 \%$ less severe (116). Several other important examples of the effects of spatial host diversity on plant disease have been reported $(24,29,66,67,70,71,87)$.

Insights into the effect of spatial heterogeneity on disease pressure may be gleaned by comparing the ecosystem services pro- 
vided by shade-grown coffee, which is grown under native or planted trees, with services provided by coffee production in intensive monocultures. Enhanced plant diversity in shade-grown coffee can contribute to increased bird predation of insect larvae (80) and elevated populations of insect commensalists that reduce damage by coffee pod borers (79). Other potential benefits resulting from the use of shade trees in coffee production include (86) increased soil organic matter and soil fauna (7); enhanced nitrogen fixation (101); reduced soil erosion, especially on steep mountain slopes; and reduced weed levels (7). On the other hand, impacts on diseases may be more variable, with evidence for both increased and decreased risk of disease, depending on the pathogen $(7,17)$.

Other reports suggest that integrating agricultural production systems into natural plant communities may enhance ecosystem services for agricultural arthropod pest management, at least in part through maintenance of predators or parasitoids in association with native plants (3). Of course, maintenance of natural enemies of vectors of plant pathogens may have direct beneficial effects on plant disease. It might also be hoped that natural plant communities maintain microbes that function as biocontrol agents against plant pathogens. Such potential benefits have obviously been difficult to study at the relevant spatial scales, though techniques for characterizing even nonculturable microbial communities are developing rapidly. In general, the utility of biocontrol microbes for management of plant disease in annual cropping systems has been limited by sensitivity to environmental fluctuations and, perhaps, also by the limited number of biocontrol species deployed $(33,111)$. On the other hand, diseasesuppressive soils offer a very interesting example of naturally occurring biological control $(10,63)$. Greater understanding of how management decisions impact disease suppressiveness will be an important factor for optimizing ecosystem management.

Some degree of temporal diversity in modern cropping systems is achieved through crop rotations, with evident benefits for disease management. For example, soil populations of the sugar beet cyst nematode (Heterodera schachtii) are reduced by rotation away from sugar beet, with a concomitant reduction in the risk of severe impacts on crop productivity (97). Of course, crop rotation may offer little or no benefit for a pathogen that produces durable resting structures and has a wide host range, such as Verticillium dahliae $(8,98)$. It is also possible that crop rotations will create conditions more favorable for disease than in monocultures, as has been shown for Fusarium head blight when wheat follows maize and maize residue is an inoculum source (27).

Just as ecosystems provide the disservice of new pathogen evolution, they also provide the service of resistance gene evolution in response to selection pressures from co-evolving pathogen populations. A heterogeneous host population is expected to select for a heterogeneous pathogen population (59), and the proportion of susceptible host types present can influence the time required for pathogen populations to overcome host resistance $(84,108)$. Plant diversity, in time or space, may provide an ecosystem service by slowing pathogen evolution to virulence.

Strategies and policy needs for conserving ecosystem services ( $\mathbf{Q}$ to $\mathbf{T})$. Conservation and utilization of genetic resources. Conservation of genetic diversity involves both preservation of current genetic diversity and maintenance of its evolution (103). Much emphasis has been placed on ex situ conservation, the preservation of current genetic diversity by creating large gene banks of crops from traditional cultivars and wild relatives (47). In addition to ex situ conservation, in situ conservation (both onfarm conservation and conservation of natural habitats, where plants are exposed to biotic and abiotic challenges and evolve in response) will be required to maintain diversity over long periods of time (47). Even in modern agricultural systems, some effort has been made to allow crop species to evolve in situ. Allowing barley to evolve in situ resulted in an increase in the frequency of five resistance genes and an overall trend toward an increase in selection for simple races of Rhynchosporium secalis (110). This barley population was developed by crossing several cultivars with each other and bulk harvesting each generation, allowing natural selection to act upon a highly diverse population. Such composite cross systems have been heralded as a way for natural selection to act upon a mixture of genotypes for the development of cultivars for low-input systems (83). Evolutionary breeding systems may be developed to include both breeders and farmers in breeding for small grains (72), allowing resistance genes to be managed directly by natural selection. Further experimentation is needed to validate the efficiency and cost-effectiveness of this strategy.

Efforts to preserve plant genetic resources have been made by national germplasm collections and international programs such as the work of centers in the Consultative Group on International Agricultural Research; however, there is a growing concern regarding making these resources accessible to everyone in the face of "... divergent but interacting interests of farmers, public- and private-sector breeders, biotechnology companies, and others" (20). The United Nations' Food and Agriculture Organization (FAO) sought to address these and other concerns related to plant genetic materials by crafting the International Treaty on Plant Genetic Resources for Food and Agriculture. The treaty took 10 years to complete due to the "...difficulties encountered in the negotiation" process (20) and came into force 29 June 2004 (32). In addition to making plant materials more readily available, it will also be important for policies to provide support for characterization of materials and ongoing evaluation of best approaches for incorporating new forms of disease resistance and other desirable traits. This is a particular concern for less-studied "orphan" crops such as quinoa and millet, which can help to provide greater diversity in farmers' portfolios and are very important in some regions but receive relatively little research attention (74).

Efforts to minimize introductions of exotic pathogens. Due to introductions of exotic pathogens on trade products, such as nursery stock in the case of the chestnut blight pathogen, regulations have been established that require inspection of trade products prior to their release and dissemination into new areas. Such inspection points can be national (inspecting imported items) or regional (inspecting items transported from one area of a country to another). In the United States, several policies have been put into place to protect American agriculture. These include the Plant Quarantine Act in 1912, the Plant Pest Act in 1957, the Federal Noxious Weed Act in 1974, the Plant Protection Act (PPA) in 2000 (which consolidates 10 previous policies), and the Agriculture Bioterrorism Protection Act in 2002 (106). Although these U.S. policies and comparable policies implemented by other countries are meant to prevent accidental introductions of exotic pathogens, there have been complaints that some groups have misused these policies to reduce imports by their competitors. In response, a policy called the Uruguay Round Agreement on Sanitary and Phytosanitary Measures was implemented by the World Trade Organization (WTO) for its member countries (107). This agreement established rules to govern when it is acceptable for member countries to have health inspections on imported goods (107). The problems in implementation of such policies result, at least in part, from the general problem of quantifying the relative risk and cost of introducing new pathogens versus the opportunity cost from limiting movement of materials. More complete valuations of ecosystem services will contribute to this analysis.

Effects of farm policy on ecosystem services. To recognize and preserve the value of ecosystem services, mechanisms to pay for these services have been developed. Such payments may be 
through mitigation markets, agreements between businesses, or government payments (23). An important example of government payments in the United States is the conservation reserve program (CRP), under which farmers are paid to manage their land for soil conservation, in some cases through planting native plant species rather than conventional crop production. In the United States, periods of low prices for traditional crops such as wheat and corn had set the stage for more direct consideration of other values from land management. However, the new price supports for biofuel production and, thus, high prices for corn and other potential biofuel crops may have reversed that trend, at least in the short run. Current agricultural systems in the United States, for example, provide highly connected networks of host availability for pathogens in many parts of the country (61). Quantifying the risk resulting from large-scale patterns of host availability will depend on improved data sets and methods for scaling up models of epidemic processes. Creating appropriate institutional frameworks for payment for ecosystem services that incorporate such large-scale processes will be an important challenge for the future.

Research needs for evaluation of plant disease in the context of ecosystem services. Ideally, analyses of ecosystem services and their response to management decisions would be applicable across the range of decision-making needed by farmers, researchers, forest or natural system managers, and policy makers. Just as for decisions to support economic optimization of yield (95), information is needed for optimization of ecosystem services in the form of short-term tactics within seasons or years, medium-term strategies across years, and long-term strategies, including policy development and optimal research programs. Farmers clearly need more complete assessments of ecosystem services in order to both obtain a reasonable return on their investments and manage their resources in the public interest. For example, what is the economic outcome of maintaining hedgerows? Under what circumstances does the farmer experience an economic benefit and under what circumstances does the public experience a benefit? Addressing such questions requires multidisciplinary assessments of ecosystem services and databases developed for this purpose (25). Such assessments will occur only to the extent that public funding is dedicated to the support of this enterprise.

A firm foundation of research will provide a basis for the establishment of appropriate public policies. Thus, for example, policy makers can be made aware of cases where ecosystem services are valuable to the public but individual property managers face disincentives to maintain those services. For these cases, it may be appropriate to develop systems of payment for ecosystem services. Policy makers must also be prepared to deal with complex issues, such as those surrounding the current interest in biofuels. Are reductions in CRP lands as a result of subsidies for biofuel production and the resulting greater homogeneity of agricultural lands likely to lead to net losses in ecosystem services? An expanded research effort will also support a more focused and defensible educational and outreach effort. Informed consumers may prefer to buy products produced with minimal negative impacts on ecosystem services but presently lack sound information on which to base their decisions. Current labeling systems such as those designating organic produce do not provide a complete assessment.

Full evaluation of ecosystem services will ultimately require a better economic valuation of the impacts of disease management and factors that impact decision making (54). What is the full economic impact of tillage operations at different scales? What is the balance of trade-offs if perennial grain crops reduce soil loss but increase disease risk (22)? What is the economic value of in situ and ex situ conservation of traditional crop cultivars and wild crop relatives that may provide disease resistance? Even in the relatively well-studied coffee systems, economic evaluation is complex because the responses of different pathogens to management decisions vary $(7,17)$. It would also be desirable to incorporate environmental indicators, such as the EIQ, into disease management studies. Classical fungicide efficacy studies could be evaluated not only in terms of disease suppression and economic returns but also for environmental impact, including impact when deviations from proper use occur because of limited applicator training. This would provide a more comprehensive assessment of the overall costs and benefits associated with disease management practices. And the need for disease management in any given region is likely to shift as a result of climate change (38). What will be the net economic effect of these changes? How resilient are ecosystem services to range shifts of plants and pathogens? Climate change will provide important and substantial challenges for understanding ecosystem services and their responses to management decisions, especially because baseline analyses are so rare for most plant pathogens and other microbes (50).

Although the study of insect communities and the effects of management choices on pests and their natural enemies have been revealing, analogous studies for microorganisms have been limited by the much greater difficulties in characterizing whole microbial communities. Now, however, modern sequencing technologies will facilitate a much more complete understanding of microbial community structure and function in response to management decisions. Pyrosequencing will support community characterization (94) and functional gene microarrays will support analysis of community function (45). These techniques will allow new types of studies of microbial communities, providing insights into the effects of different management decisions on the balance of species that provide services and disservices. There will still be a great deal of work to determine which microbial species fill which role under what circumstances. These new types of information will support strategies for the conservation biology of microbes that function as biocontrol agents and provide information about the impact of pathogens on plant associations with mycorrhizal fungi and rhizobia. Do some microbial community structures provide services by facilitating induced or acquired plant disease resistance (111)? New approaches such as these will ultimately facilitate evaluation of antibiotics produced by plant pathogens and associated microbes that may have applications in medicine.

The relationship between biodiversity and disease regulation is a particularly interesting one for plant disease. As discussed above, plant biodiversity will tend to reduce plant disease risk but there are important exceptions where inclusion of particular plant species in plant communities may increase disease risk. A key for clarifying this relationship is determining the functional diversity and composition of plant communities. If intraspecific plant functional diversity for disease resistance is higher, the effect of diversity on disease is likely to be more beneficial for disease management (38). If plant diversity includes a range of functions that support different phases of pathogen lifecycles, such as supporting sexual reproduction (82) or providing temporal or spatial green bridges (11), those components of diversity may result in greater disease risk. In the case of microbial diversity, new sequencing and microarray tools will make it possible to address exciting new questions. Do more diverse plant communities support microbial communities that supply more or higher quality services? Do more diverse microbial communities offer more or higher quality services; or, what type of filling of microbial taxonomic or functional space is optimal for particular scenarios?

The analysis of disease and disease management effects on ecosystem services will require good models for upscaling models of epidemic processes. For example, is it a good strategy to "sacrifice" some areas to intensive agricultural production at the expense of other services, with the hope of preserving other 
natural areas that might otherwise be converted to agriculture (31)? At larger scales, natural areas may act as barriers to disease movement between agricultural areas. What are the effects of landscape fragmentation at different scales on disease risk? More information about large-scale epidemic processes is needed for plant pathologists to fully contribute to debates about optimal land use patterns. Use of geographic information systems (GIS) has added much power to the study of plant diseases (73) and this technology can certainly be useful for exploring links between plant disease and ecosystem services. Spatially explicit information about estimated fungicide use based on disease severity estimated from process models (46) could provide spatial predictions of expected health and environmental risks. Recently, environmental indicators were used in GIS to evaluate pesticide exposure risk in Belgium (21). These methods could potentially be used by plant pathologists to evaluate the effects on ecosystem services from pesticide reduction due to improved disease management approaches.

Attempts to better position research on plant diseases within the context of ecosystem services must overcome many challenges and cannot succeed without extensive cross-disciplinary collaborations. Educational systems for plant pathologists should prepare them for collaboration with ecologists, entomologists, health specialists, and economists specializing in valorization of services. Likewise, members of these disciplines should have an appreciation for the role of plant pathogens in agricultural and wildland ecosystem services. Ultimately, these efforts should be repaid as they contribute to development of more sustainable agricultural practices and a more holistic approach to environmental stewardship.

\section{ACKNOWLEDGMENTS}

This synthesis was prepared as part of a Distributed Graduate Seminar (DGS) 'Biodiversity, conservation and ecosystem services in managed landscapes', conducted through the U.S. National Center for Ecological Analysis and Synthesis, a Center funded by NSF (Grant DEB-0553768), the University of California, Santa Barbara, and the State of California. M. R. Cheatham and M. N. Rouse were student leaders for the synthesis, K. A. Garrett and T. R. Gordon were DGS faculty leaders, G. A. Forbes was faculty leader at CIP, and other contributors appear in alphabetical order. We thank P. Garfinkel, M. Kennelly, an anonymous reviewer, and other members of the DGS for their comments; N. Paul, who was very generous with his time and attention in editing this manuscript; and the USAID for the SANREM CRSP (No. EPP-A-00-04-00013-00) and IPM CRSP (No. EPP-A-00-04-00016-00) to the OIRD at Virginia Tech, NSF Grants DEB-0130692, DEB-0516046, and EF-0525712 (as part of the joint NSF-NIH Ecology of Infectious Disease program), United States Department of Agriculture grant 2002-34103-11746, and the Kansas State Experiment Station (Contribution No. 08-140-J) for their support.

\section{LITERATURE CITED}

1. Agrios, G. N. 2005. Plant Pathology, 5th ed. Academic Press, San Diego, CA.

2. Al-Kaisi, M. M., and Hanna, M. 2002. Residue Management and Cultural Practices. Publ. No. PM 1901a. Iowa State University, Cooperative Extension Service, Ames.

3. Andow, D. A. 1991. Vegetational diversity and arthropod population response. Annu. Rev. Entomol. 36:561-586.

4. Anonymous. 1991. Protecting the Nation's Ground Water: EPA's Strategy for the 1990s, The Final Report of the EPA Ground-Water Task Force. Environmental Protection Agency, Washington, DC.

5. Arbuckle, K., and Pease, J. L. 1999. Managing Iowa Habitats: Linear Habitats in Rural Landscapes. Publ. No. PM 1351k. Iowa State University, Cooperative Extension Service, Ames.

6. Ball, E., Färe, R., Grosskopf, S., and Zaim, O. 2005. Accounting for externalities in the measurement of productivity growth: The Malmquist cost productivity measure. Struct. Change Econ. Dynamics 16:374-394.

7. Beer, J., Muschler, R., Kass, D., and Somarriba, E. 1997. Shade management in coffee and cacao plantations. Agrofor. Syst. 38:139-164.
8. Bhat, R. G., and Subbarao, K. V., 1999. Host range specificity in Verticillium dahliae. Phytopathology 89:1218-1225.

9. Bolker, B. M. 1999. Analytic models for the patchy spread of plant disease. Bull. Math. Biol. 61:849-874.

10. Borneman, J., and Becker, J. O. 2007. Identifying microorganisms involved in specific pathogen suppression in soil. Annu. Rev. Phytopathol. 45:153-172.

11. Bowden, R. L., Brooks, H. L., Peterson, D. E., and Shroyer, J. P. 1991. Be a Good Neighbor: Control Your Volunteer Wheat. Publ. No. MF-1004. Kansas State University, Agricultural Experiment Station and Cooperative Extension Service, Manhattan.

12. Brewer, L. G. 1995. Ecology of survival and recovery from blight in American chestnut trees (Castanea dentata (Marsh.) Borkh.) in Michigan. Bull. Torrey Bot. Club 122:40-57.

13. Burdon, J. J., Jarosz, A. M., and Kirby, G. C. 1989. Pattern and patchiness in plant-pathogen interactions-causes and consequences. Annu. Rev. Ecol. Syst. 20:119-136.

14. Cahill, D. M., Rookes, J. E., Wilson, B. A., Gibson, L., and McDougall, K. L. 2008. Phytophthora cinnamomi and Australia's biodiversity: Impacts, predictions and progress towards control. Aust. J. Bot. 56:279310 .

15. Caraco, T., Duryea, M. C., Glavanakov, S., Maniatty, W., and Szymanski, B. K. 2001. Host spatial heterogeneity and the spread of vector-borne infection. Theor. Popul. Biol. 59:185-206.

16. Castello, J. D., Leopold, D. J., and Smallidge, P. J. 1995. Pathogens, patterns, and processes in forest ecosystems. BioScience 45:16-24.

17. Chen, J., Saunders, S. C., Crow, T. R., Naiman, R. J., Brosofske, K. D., Mroz, G. D., Brookshire, B. L., and Franklin, J. F. 1999. Microclimate in forest ecosystem and landscape ecology. BioScience 49:288-297.

18. Chen, S. K., Edwards, C. A., and Subler, S. 2001. Effects of the fungicides benomyl, captan and chlorothalonil on soil microbial activity and nitrogen dynamics in laboratory incubations. Soil Biol. Biochem. 33:1971-1980.

19. Christian, M. L., and Willis, W. G. 1993. Survival of wheat streak mosaic virus in grass hosts in Kansas from wheat harvest to fall wheat emergence. Plant Dis. 77:239-242.

20. Cooper, H. D. 2002. The International Treaty on Plant Genetic Resources for Food and Agriculture. Review of European Community \& International Environmental Law 11:1-16. doi:10.1111/1467-9388. 00298.

21. Cornelis, C., Schoeters, G., Kellen, E., Buntinx, F., and Zeegers, M. 2009. Development of a GIS-based indicator for environmental pesticide exposure and its application to a Belgian case-control study on bladder cancer. Int. J. Hyg. Environ. Health 212:172-185.

22. Cox, C. M., Garrett, K. A., and Bockus, W. W. 2005. Meeting the challenge of disease management in perennial grain cropping systems. Renewable Agric. Food Syst. 20:15-24.

23. Daily, G. C., ed. 1997. Nature's Services: Societal Dependence on Natural Ecosystems. Island Press, Washington, DC.

24. Davidson, J. M., Wickland, A. C., Patterson, H. A., Falk, K. R., and Rizzo, D. M. 2005. Transmission of Phytophthora ramorum in mixedevergreen forest in California. Phytopathology 95:587-596.

25. de Groot, R. S., Wilson, M. A., and Boumans, R. M. J. 2002. A typology for the classification, description and valuation of ecosystem functions, goods and services. Ecol. Econ. 41:393-408.

26. DeLorenzo, M. E., and Serrano, L. 2003. Individual and mixture toxicity of three pesticides; atrazine, chlorpyrifos, and chlorothalonil to the marine phytoplankton species Dunaliella tertiolecta. J. Environ. Sci. Health Part A 38:529-538.

27. Dill-Macky, R., and Jones, R. K. 2000. The effect of previous crop residues and tillage on Fusarium head blight of wheat. Plant Dis. 84:7176.

28. Dumestre, A., Sauve, S., McBride, M., Baveye, P., and Berthelin, J. 1999. Copper speciation and microbial activity in long-term contaminated soils. Arch. Environ. Contam. Toxicol. 36:124-131.

29. Emiko Condeso, T., Ross, K., and Meentemeyer, R. K. 2007. Effects of landscape heterogeneity on the emerging forest disease sudden oak death. J. Ecol. 95:364-375.

30. Eviner, V. T., and G. E. Likens. 2008. Effects of pathogens on terrestrial ecosystem function. Pages 260-283 in Infectious Disease Ecology: Effects of Ecosystems on Disease and of Disease on Ecosystems. R. S. Ostfeld, F. Keesing, and V. Eviner, eds. Princeton University Press, Princeton, NJ.

31. Fischer, J., Brosi, B., Daily, G. C., Ehrlich, P. R., Goldman, R., Goldstein, J., Lindenmayer, D. B., Manning, A. D., Mooney, H. A., Pejchar, L., Ranganathan, J., and Tallis, H. 2008. Should agricultural policies encourage land sparing or wildlife-friendly farming? Front. Ecol. Environ. 6:380-385.

32. Food and Agriculture Organization of the United Nations (FAO-UN). 2006. History of the Treaty. Fact Sheet No. 8. International Treaty on 
Plant Genetic Resources for Food and Agriculture. FAO-UN, Rome, Italy.

33. Fravel, D. R. 2005. Commercialization and implementation of biocontrol. Annu. Rev. Phytopathol. 43:337-359.

34. Gallivan, G. J., Berges, H., and McGee, B. 2005. Evaluation of the Changes in Pesticide Risk. Research Project SR9128: Survey of Pesticide Use and Evaluation of the Changes in Pesticide Risk on Agricultural Crops in Ontario. Ontario Ministry of Agriculture and Food, Guelph, ON, Canada.

35. Garrett, K. A., and Cox, C. M. 2008. Applied biodiversity science: managing emerging diseases in agriculture and linked natural systems using ecological principles. Pages 368-386 in: Infectious Disease Ecology: Effects of Ecosystems on Disease and of Disease on Ecosystems. R. Ostfeld, F. Keesing, and V. Eviner, eds. Princeton University Press, Princeton, NJ.

36. Garrett, K. A., Dendy, S. P., Frank, E. E., Rouse, M. N., and Travers, S. E. 2006. Climate change effects on plant disease: genomes to ecosystems. Annu. Rev. Phytopathol. 44:489-509.

37. Garrett, K. A., and Mundt, C. C. 1999. Epidemiology in mixed host populations. Phytopathology 89:984-990.

38. Garrett, K. A., Zúñiga, L. N., Roncal, E., Forbes, G. A., Mundt, C. C., $\mathrm{Su}, \mathrm{Z}$., and Nelson, R. J. Intraspecific functional diversity in hosts and its effect on disease risk across a climate gradient. Ecol. Appl. 19:18681883.

39. Garthwaite, D. G. 1996. Greener than they think? Turf Manage. March:18.

40. Gestel, C. A. M. v., Koolhaas, J. E., Schallnass, H. J., Rodrigues, J. M. L., and Jones, S. E. 2004. Ring-testing and field-validation of a Terrestrial Model Ecosystem (TME) — an instrument for testing potentially harmful substances: Effects of carbendazim on nutrient cycling. Ecotoxicology 13:119-128.

41. Gilbert, G. S. 2002. Evolutionary ecology of plant diseases in natural ecosystems. Annu. Rev. Phytopathol. 40:13-43.

42. Gordon, T. R., Storer, A. J., and Wood, D. L. 2001. The pitch canker epidemic in California. Plant Dis. 85:1128-1139.

43. Groot, J, Rossing, W., Jellema, A., Stobbelaar, D., Renting, H., and Van Ittersum, M. 2007. Exploring multi-scale trade-offs between nature conservation, agricultural profits and landscape quality - a methodology to support discussions on land-use perspectives. Agric. Ecosyst. Environ. 120:58-69.

44. Hajjar, R., Jarvis, D. I., and Gemmill-Herren, B. 2008. The utility of crop genetic diversity in maintaining ecosystem services. Agric. Ecosyst. Environ. 124:261-270.

45. He, Z. L., Gentry, T. J., Schadt, C. W., Wu, L. Y., Liebich, J., Chong, S. C., Huang, Z. J., Wu, W. M., Gu, B. H., Jardine, P., Criddle, C., and Zhou, J. 2007. GeoChip: a comprehensive microarray for investigating biogeochemical, ecological and environmental processes. ISME J. 1:6777 .

46. Hijmans, R. J., Forbes, G. A., and Walker, T. S. 2000. Estimating the global severity of potato late blight with GIS-linked disease forecast models. Plant Pathol. 49:697-705.

47. Hodgkin, T., and Rao, V. R. 2002. People, plants and DNA: Perspectives on the scientific and technical aspects of conserving and using plant genetic resources. Pages 469-480 in: Managing Plant Genetic Diversity. J. M. Engels, V. R. Rao, A. H. Brown, and M. T. Jackson, eds. CABI Publishing, Makati City, The Philippines.

48. Houston, D. R. 1975. Beech bark disease-the aftermath forests are structured for a new outbreak. J. For. 73:660-663.

49. Huber, L., and T. J. Gillespie. 1992. Modeling leaf wetness in relation to plant disease epidemiology. Annu. Rev. Phytopathol. 30:553-577.

50. Jeger, M. J., and Pautasso, M. Plant disease and global change-the importance of long-term data sets. New Phytol. 177:8-11.

51. Jiang, W., Garrett, K. A., Peterson, D. W., Harvey, T. L., Bowden, R. L., and Fang, L. 2005. The window of risk for emigration of Wheat streak mosaic virus varies with host eradication method. Plant Dis. 89:853-858.

52. Jones-Lepp, T. L., Varner, K. E., and Heggem, D. 2004. Monitoring dibutyltin and triphenyltin in fresh waters and fish in the United States using micro-liquid chromatography-electrospray/ion trap mass spectrometry. Arch. Environ. Contam. Toxicol. 46:90-95.

53. Keesing, F., Holt, R. D., and Ostfeld, R. S. 2006. Effects of species diversity on disease risk. Ecol. Lett. 9:485-498.

54. Klein, E., Laxminarayan, R., Smith, D. L., and Gilligan, C. A. 2007. Economic incentives and mathematical models of disease. Environ. Dev. Econ. 12:707-732.

55. Koniecki, D., Newhook, R., Long, G., de Beyssac, B.C., and Socha, A. 1997. Screening candidate substances for the second priority substances list under the Canadian Environmental Protection Act. Environ. Carcin. Ecotoxicol. Rev. C15:41-59.

56. Kovach, J., Petzoldt, C., Degni, J., and Tette, J. 1992. A method to measure the environmental impact of pesticides. N. Y. Food Life Sci. Bull.
139:1-8.

57. Krishnayyaand, P. V., and Grewal, P. S. 2002. Effect of neem and selected fungicides on viability and virulence of the entomopathogenic nematode Steinernema feltiae. Biocontrol Sci. Technol. 12:259-266.

58. Lagnaoui, A., and Radcliffe, E. 1998. Potato fungicides interfere with entomopathogenic fungi impacting population dynamics of green peach aphid. Am. J. Potato Res. 75:19-25.

59. Lannou, C., and Mundt, C. C. 1996. Evolution of a pathogen population in host mixtures: simple race-complex race competition. Plant Pathol. 45:440-453.

60. Lee, C. C., Wang, T., Hsieh, C. Y., and Tien, C. J. 2005. Organotin contamination in fishes with different living patterns and its implications for human health risk in Taiwan. Environ. Pollut. 137:198-208.

61. Margosian, M. L., Garrett, K. A., Hutchinson, J. M. S., and With, K. A. 2009. Connectivity of the American agricultural landscape: Assessing the national risk of crop pest and disease spread. BioScience 59:141-151.

62. Markey, K. L., Baird, A. H., Humphrey, C., and Negri, A. P. 2007. Insecticides and a fungicide affect multiple coral life stages. Mar. Ecol. Prog. Ser. 330:127-137.

63. Mazzola, M. 2004. Assessment and management of soil microbial community structure for disease suppression. Annu. Rev. Phytopathol. 42:35-59.

64. Millennium Ecosystem Assessment. 2005. Ecosystems and Human Wellbeing: Synthesis. Island Press, Washington, DC

65. Miller, G. A., Amemiya, M., Jolly, R. W., Melvin, S. W., and Nowak, P. J. 1999. Soil Erosion and the Iowa Soil 2000 Program. Publ. No. PM-1056. Iowa State University Cooperative Extension Service, Ames.

66. Mitchell, C. E., Reich, P. B., Tilman, D., and Groth, J. V. 2003. Effects of elevated $\mathrm{CO}_{2}$, nitrogen deposition, and decreased species diversity on foliar fungal plant disease. Global Change Biol. 9:438-451.

67. Mitchell, C. E., Tilman, D., and Groth, J. V. 2002. Effects of grassland plant species diversity, abundance, and composition on foliar fungal disease. Ecology 83:1713-1726.

68. Mittelbach, G. G., Steiner, C. F., Scheiner, S. M., Gross, K. L., Reynolds, H. L., Waide, R. B., Willig, M. R., Dodson, S. I., and Gough, L. 2001. What is the observed relationship between species richness and productivity? Ecology 82:2381-2396.

69. Mundt, C. C. 2002. Use of multiline cultivars and cultivar mixtures for disease management. Annu. Rev. Phytopathol. 40:381-410.

70. Mundt, C. C., and Leonard, K. J. 1986. Analysis of factors affecting disease increase and spread in mixtures of immune and susceptible plants in computer-simulated epidemics. Phytopathology 76:832-840.

71. Mundt, C. C., and Leonard, K. J. 1986. Effect of host genotype unit area on development of focal epidemics of bean rust and common maize rust in mixtures of resistant and susceptible plants. Phytopathology 76:895900 .

72. Murphy, K., Lammer, D., Lyon, S., Carter, B., and Jones, S. S. 2005. Breeding for organic and low-input farming systems: An evolutionaryparticipatory breeding method for inbred cereal grains. Renewable Agric. Food Syst. 20:48-55

73. Nelson, M. R., Orum, T. V., Jaime-Garcia, R., and Nadeem, A. 1999. Applications of geographic information systems and geostatistics in plant disease epidemiology and management. Plant Dis. 83:308-319.

74. Nelson, R. J., Naylor, R. L., and Jahn, M. M. 2004. The role of genomics research in improvement of "orphan" crops. Crop Sci. 44:1901-1904.

75. Neuenschwander, L. F., Byler, J. W., Harvey, A. E., McDonald, G. I., Ortiz, D. S., Osborne, H. L., Snyder, G. C., and Zack, A. 1999. White pine in the American West: A vanishing species-can we save it? U.S. For. Serv. Rocky Mt. Res. Stn. Gen. Tech. Rep. RMRSGTR-35.

76. Oerke, E. C., Dehne, D. W., Schonbeck, F., and Weber, A. 1994. Crop Production and Crop Protection: Estimated Losses in Major Food and Cash Crops. Elsevier, Amsterdam.

77. Ortiz, O., and Forbes, G. A. 2003. Farmers' knowledge and practices regarding fungicide use for late blight control in the Andes. Pages 45-56 in: Proc. Int. Workshop Complementing Resistance to Late Blight (Phytophthora infestans) in the Andes. D. N. Fernandez Northcote, ed. International Potato Center, Lima, Peru.

78. Pease, W. S., Liebman, J., Landy, D., and Albright, D. 1996. Pesticide use in California. Strategies for reducing environmental health impacts. California Policy Seminar. University of California, Berkeley.

79. Perfecto, I., and Vandermeer, J. 2006. The effect of an ant-hemipteran mutualism on the coffee berry borer (Hypothenemus hampei) in southern Mexico. Agric. Ecosyst. Environ. 117:218-221.

80. Perfecto, I., Vandermeer, J. H., López Bautista G., Ibarra Nuñez, G., Greenberg, R., Bichier, P., and Langridge, S. 2004. Greater predation in shaded coffee farms: the role of resident neotropical birds. Ecology 85:2677-2681.

81. Perkins, T. E., and Matlack, G. R. 2002. Human-generated pattern in 
commercial forests of southern Mississippi and consequences for the spread of pests and pathogens. For. Ecol. Manage. 157:143-154.

82. Peterson, P. D., Leonard, K. J., Roelfs, A. P., and Sutton, T. B. 2005. Effect of barberry eradication on changes in populations of Puccinia graminis in Minnesota. Plant Dis. 89:935-940.

83. Phillips, S. L., and Wolfe, M. S. 2005. Evolutionary plant breeding for low input systems. J. Agric. Sci. 143:245-254.

84. Pietravalle, S., Lemarie, S., and van den Bosch, F. 2006. Durability of resistance and cost of virulence. Eur. J. Plant Pathol. 114:107-116.

85. Pietrzak, U., and McPhail, D. C. 2004. Copper accumulation, distribution and fractionation in vineyard soils of Victoria, Australia. Geoderma 122:151-166.

86. Polzot, C. L. 2004. Carbon storage in coffee agroecosystems of Southern Costa Rica: potential application for the clean development mechanism. M.S. thesis, York University, Toronto.

87. Power, A. G., and Mitchell, C. E. 2004. Pathogen spillover in disease epidemics. Am. Nat. 184:S79-S89.

88. Pradel, W., Yanggen, D., and Polastri, N. 2006. Trade offs between economic returns and methane greenhouse gas emissions in dairy production systems in Cajamarca, Peru. Livestock Res. Rural Dev. Int. Electron. Mag. 18:41.

89. Ribéreau-Gayon, J., Ribéreau-Gayon, P., and Seguin, G. 1980. Botrytis cinerea in enology. Pages 251-274 in: The Biology of Botrytis. J. R. Coley-Smith, K. Verhoeff, and W. R. Jarvis, eds. Academic Press, New York

90. Rizzo, D. M., Garbelotto, M., Davidson, J. M., Slaughter, G. W., and Koike, S. T. 2002. Phytophthora ramorum as the cause of extensive mortality of Quercus spp. and Lithocarpus densiflorus in California. Plant Dis. 86:205-214.

91. Rizzo D. M., Slaughter, G. W., and Parmeter, J. R. 2000. Enlargement of canopy gaps associated with a fungal pathogen in Yosemite Valley, California. Can. J. For. Res. 30:1501-1510.

92. Robertson, G. P., and Swinton, S. M. 2005. Reconciling agricultural productivity and environmental integrity: A grand challenge for agriculture. Front. Ecol. Environ. 3:38-46.

93. Rodgers, R. D. 1999. Why haven't pheasant populations in western Kansas increased with CRP? Wildlife Soc. Bull. 27:654-665.

94. Roesch, L. F., Fulthorpe, R. R., Riva, A., Casella, G., Hadwin, A. K. M, Kent, A. D., Daroub, S. H., Camargo, F. A. O, Farmerie, W. G., and Triplett, E. W. 2007. Pyrosequencing enumerates and contrasts soil microbial diversity. ISME J. 1:283-290.

95. Savary, S., Teng, P. S., Willocquet, L., and Nutter, F. W., Jr. 2006. Quantification and modeling of crop losses: a review of purposes. Annu. Rev. Phytopathol. 44:89-112.

96. Scheffer, R. J., Voeten, J. G. W. F., and Guries, R. P. 2008. Biological control of Dutch elm disease. Plant Dis. 92:192-200.

97. Schmidt, K., Sikora, R. A., and Richter, O. 1993. Modeling the population dynamics of the sugar beet cyst nematode Heterodera schachtii. Crop Prot. 12:490-496.

98. Schnathorst, W. C. 1981. Life cycle and epidemiology of Verticillium. Pages 81-144 in: Fungal Wilt Diseases of Plants. M. E. Mace, A. A. Bell, and C. H. Beckman, eds. Academic Press, London.

99. Seifers, D. L., Harvey, T. L., Kofoid, K. D., and Stegmeier, W. D. 1996. Natural infection of pearl millet and sorghum by wheat streak mosaic virus in Kansas. Plant Dis. 8:179-185.
100. Smith, M. D., Hartnett, D. C., and Rice, C. W. 2000. Effects of longterm fungicide applications on microbial properties in tallgrass prairie soil. Soil Biol. Biochem. 32:935-946.

101. Soto-Pinto, L., Perfecto, I., and Caballero, N. J. 2004. Shade over coffee: its effects on berry borer, leaf rust and spontaneous herbs in Chiapas, Mexico. Agrofor. Syst. 55:37-45.

102. Strange, R. N., and P. R. Scott. 2005. Plant disease: A threat to global food security. Annu. Rev. Phytopathol. 43:83-116.

103. Swaminathan, M. S. 2002. The past, present and future contributions of farmers to the conservation and development of genetic diversity. Pages 23-31 in: Managing Plant Genetic Diversity. J. M. Engels, V. R. Rao, A. H. Brown, and M. T. Jackson, eds. CABI Publishing, Makati City, The Philippines.

104. Tegtmeier, E. M., and Duffy, M. 2004. External costs of agricultural production in the United States. Int. J. Agric. Sustain. 2:1-20.

105. Thiele, G., Navia, O., and Fernandez Northcote, E. N. 1998. Economic analysis of the strategy for chemical control of late blight (Phytophthora infestans) in susceptible potato cultivars in Cochabamba, Bolivia. Fitopatología 33:176-181.

106. United States Department of Agriculture (USDA), Animal and Plant Health Inspection Service (APHIS). 2007. APHIS Plant Inspection Stations: Protecting American Agriculture from Foreign Pests and Diseases. USDA, Washington, DC.

107. United States Department of Agriculture (USDA), Foreign Agriculture Service (FAS). 2006. Sanitary and Phytosanitary Measures and the World Trade Organization. USDA, Washington, DC

108. Van den Bosch, F., and C. A. Gilligan. 2003. Measures of durability of resistance. Phytopathology 93:616-625.

109. Van-Zwieten, L., Merrington, G., and Van-Zwieten, M. 2004. Review of impacts on soil biota caused by copper residues from fungicide application. In: SuperSoil 2004: 3rd Australian New Zealand Soils Conference. University of Sydney, Sydney, Australia.

110. Webster, R. K., Saghai-Maroof, M. A., and Allard, R. W. 1986. Evolutionary response of barley composite cross II to Rhynchosporium secalis analyzed by pathogenic complexity and gene-by-race relationships. Phytopathology 76:661-668.

111. Whipps, J. M. 2001. Microbial interactions and biocontrol in the rhizosphere. J. Exp. Bot. (Roots Spec. Issue) 52:487-511.

112. Wikler, K., Storer A. J., Newman, W., Gordon, T. R., and Wood, D. L. 2003. The dynamics of an introduced pathogen in a native Monterey pine (Pinus radiata) forest. For. Ecol. Manage. 179:209-221.

113. With, K. A. 2002. The landscape ecology of invasive spread. Conserv. Biol. 16:1192-1203.

114. Wortman, C. S., Helmers, M., Mallarino, A., Barden, C., Devlin, D., Pierzynski, G., Lory, J., Massey, R., Holz, J., Shapiro, C., and Kovar, J. 2005. Agricultural Phosphorus Management and Water Quality Protection in the Midwest. Publ. No. RP187. University of NebraskaLincoln, Lincoln.

115. Yanggen, D., Cole, D. C., Crissman, C., and Sherwood, S. 2004. Pesticide use in commercial potato production: Reflections on research and intervention efforts towards greater ecosystems health in northern Ecuador. EcoHealth 1:SU72-SU83.

116. Zhu, Y., Chen, H., Fan, J., Wang, Y., Li, Y., Chen, J., Fan, J., Yang, S., Hu, L., Leung, H., Mew, T. W., Teng, P. S., Wang, Z., and Mundt, C. C. 2000. Genetic diversity and disease control in rice. Nature 406:718-722. 